\title{
Midnight in Paris (Woody Allen, 2011): la omisión del pasado como constitu- yente de la identidad urbana presente
}

\author{
'Midnight in Paris' (Woody Allen, 2011): \\ the omission of the past as a constituent \\ of the present urban identity \\ Mónica Tovar Vicente \\ Becaria FPU. Universidad Complutense de Madrid \\ monica.tovar.vicente@gmail.com
}

Recibido: $27 / 02 / 2014$

Aceptado: 21/03/2014

\begin{abstract}
Resumen
Desde hace unos años, el cineasta norteamericano Woody Allen está dedicando sus narraciones a diferentes ciudades europeas. En la mayoría de ellas el referente urbano ya hace acto de presencia en los propios títulos comenzando en España con Vicky, Cristina, Barcelona (2008), continuando en el país vecino a través de Midnight in Paris (2011) y culminando en 'la bota' con A Roma con amor (2012). En este artículo se analiza el segundo de los largometrajes tomando como referencia el diálogo pasado-presente en el que se sustenta, y que revela cómo el realizador, además de presentar a los iconos parisinos por excelencia, siempre identificables y localizables, también cede tiempo de expresión a esos otros espacios menos conocidos en términos turísticos llegando, sin embargo, a negarle a varios de ellos su existencia en la actualidad. En suma, un acercamiento al retrato de la ville lumière de ayer y hoy que firma Allen.
\end{abstract}

Palabras clave

Parcours, turista-espectador, distrito/arrondisement ( $\left.\mathrm{n}^{\mathrm{ème}}\right)$, discurso, narrativa 


\begin{abstract}
For a few years, the North American filmmaker Woody Allen is dedicating his films to different European cities. In the majority of them the urban referent is already present in the own titles beginning in Spain with Vicky, Cristina, Barcelona (2008), continuing in the neighboring country through Midnight in Paris (2011) and culminating in 'the boot' with A Rome with love (2012). This article analyzes the second film having as the principal point of study the dialogue past-present which is the center of the narration and, equally, reveals how the director, as well as presents the Parisians icons, always identifiable and localizable, expresses the other spaces, less known in touristic terms, but, without its real present identity for the majority of the cases. In sum, an approach to the portrait of the ville lumière (in its past and present state) signed by Allen.
\end{abstract}

\title{
Keywords
}

Parcours, touristic-spectator, district/arrondissement (nème), discours, narrative

Referencia normalizada: TOVAR VICENTE, MóNICA (2014): “Midnight in Paris (Woody Allen, 2011): la omisión del pasado como constituyente de la identidad urbana presente". Arte y Ciudad. Revista de Investigación, no 5 (abril), págs. 7-40). Madrid. Grupo de Investigación Arte, Arquitectura y Comunicación en la Ciudad Contemporánea, Universidad Complutense de Madrid.

Sumario: 1.- La medianoche parisina de Allen como atractivo turístico. 1.1.- Contexto general de las iniciativas fílmico-gubernamentales de la ville lumière. 1.2.- Recorridos cinematográficos: la experiencia del parcours de Midnight in Paris. 2.- Woody Allen: un cineasta europeo con una mirada.... 2.1.- Títulos de crédito iniciales: una oda a lo turística y típicamente parisino. 2.2.- La urbe en el tiempo presente: París lujo, París icónico, París turístico. 2.3.- El París de los años 20: la negación de una época en la metrópoli actual. 3.- Conclusiones: medianoche en un París pluridentitario anhelado en el presente. 4.- Bibliografía. 


\section{La medianoche parisina de Allen como atractivo turístico.}

El cine es una gran invitación a viajar. Seleccionando espacios y monumentos de una vida nueva, los revela, los hace intrigantes o cautivadores, despierta en nosotros la necesidad de conocerlos. En Francia, dos tercios de los turistas extranjeros reconocen haberse visto influenciados por el visionado de una película y un conjunto numeroso de franceses también lo corroboran. En el momento en el que una parte del mercado cinematográfico galo se alza a un nivel históricamente elevado, es cuando se percibe que la producción francesa es la primera de Europa y la tercera del mundo tras los Estados Unidos y la India, se mide el papel que el cine ejerce en la atracción de nuestro país (Ganne, 2009: 1. Trad. M. Tovar)

\subsection{Contexto general de las iniciativas fílmico-gubernamentales de la ville lumière.}

Como expresan los autores franceses Valérie Ganne, Caroline JulliardMourgues y Franck Priot en su trabajo Tourisme et tournage des films. Comment dynamiser son territoire par l'audiovisuel (2009), cada vez es más notable y aceptado que las producciones del séptimo arte tienen unas consecuencias directas para la potenciación de la urbe como recurso turístico y, consecuentemente, económico. Este hecho ha implicado, como dejan entrever en su postulado, el nacimiento de una nueva figura visitante: la del turista-espectador, aquel que acude a la ciudad motivado por la visión de uno o más largometrajes rodados en sus dimensiones y que, actualmente, cuenta con una gran diversidad de medios y recursos (blogs, webs, enciclopedias, etc.) para recorrer la ciudad siguiendo las localizaciones de un título fílmico específico, reviviendo las situaciones previamente experimentadas por los personajes del mismo.

París es, posiblemente, la metrópoli con la identidad cinematográfica más arraigada. Partiendo de la premisa que fue en la capital gala donde se realizó la primera proyección pública de una creación fílmica (los cortos rodados por los hermanos Louis y Auguste Lumière), su presencia en el séptimo arte no sólo se ha mantenido a lo largo de su desarrollo como actividad artística y comercial, sino que, al mismo tiempo, se ha visto potenciada. París siempre ha sido un decorado con especial interés para las productoras, guionistas y directores hollywoodienses (Tovar, 2013). Conscientes de esta repercusión, las autoridades parisinas no han dudado en desarrollar diferentes estrategias y programas para 
aprovechar el impacto que ejercen sobre el potencial turista-espectador las producciones nacionales y extranjeras. Si bien, como se analiza en este trabajo, ofrecer los recorridos y desvelar los escenarios urbanos que han sido retratados por la cámara son dos de sus principales actividades, otras se orientan hacia la facilitación de los rodajes en sus diferentes barrios y distritos, lo que explica que, efectivamente, sea una de las urbes más filmadas. De este modo, por ejemplo, la coproducción es uno de los modelos más protegidos a la par que favorecidos como explica el Centre National du Cinéma en su anuario del año pasado:

Los acuerdos intergubernamentales de coproducción permiten atribuir la doble nacionalidad a las películas coproducidas y hacerlas, así, beneficiarse de ventajas, ayudas y subvenciones reservadas a las creaciones nacionales de cada uno de los países participantes. (...)En total, Francia cuenta con 52 acuerdos de coproducción con países de los cinco continentes, ubicándose, así, notablemente a la cabeza de los países europeos. (2013: 25. Trad. M. Tovar)

Estos acuerdos que favorecen el posicionamiento de equipos internacionales en las metrópolis francesas y, por lo general y dado su atractivo, en la capital, explican, en gran parte, las cifras destacadas que los rodajes alcanzan en las diferentes memorias anuales. Así, para la del 2010, cuando se rueda Midnight in Paris ${ }^{1}$, Mission Cinéma, programa del Ayuntamiento parisino que persigue impulsar una política coherente y favorable para el séptimo arte $^{2}$, recoge los siguientes datos: un incremento en 70 filmaciones con desarrollo en la urbe (pasando de las 850 de 2009 a las 920 del año siguiente), una media de 9 rodajes diarios; de cada dos películas francesas, una se rueda en la capital y más de 5.000 espacios de la metrópoli ejercieron como decorados o localizaciones. De los diversos tipos de piezas audiovisuales que se produjeron, los largometrajes, 110 en total, se posicionan en penúltimo lugar siendo superados por los spots

${ }^{1}$ En este sentido conviene aclarar que, si bien la película fue rodada en ese año, no fue hasta mayo del siguiente cuando se estrenó en las salas a nivel internacional. Igualmente, hacemos hincapié en que, siempre que las producciones hayan sido estrenadas en España, son indicadas con el título con el que se las comercializó en este país. Por el contrario, la cifra numérica que las acompaña remite al estreno en su país de origen, ya que no siempre son coincidentes en uno y otro.

2 Este objetivo se desarrolla en base a seis ramas o líneas de trabajo: la producción de cortometrajes, los rodajes, las salas de arte y ensayo independientes, los festivales y eventos cinematográficos, el Forum des Images (entidad encargada de preservar, sustentar y desarrollar la memoria audiovisual de la capital gala) y la educación en el cine. 
publicitarios y videoclips (141), las series y películas de televisión (132), los cortometrajes (161) y las creaciones escolares y universitarias (176). Únicamente es inferior el cómputo de documentales que ascendió a 69 títulos. Si se centra el análisis en las películas, naturaleza que presenta el objeto analizado, se revela que la media de días de rodaje en la metrópoli parisina fue de 10, identificándose entre los realizadores extranjeros que trabajaron dentro del marco de la ville lumière a Allen junto a otros nombres como los de Martin Scorsese ( $L a$ invención de Hugo, 2011, Estados Unidos), Jean-Marc Vallée (Café de Flore, 2011, Canadá) o Jeremy Leven (Girl on a bicycle, 2013, Alemania).

Según se viene defendiendo, la postura que las diferentes autoridades parisinas tienen para con la actividad cinematográfica es positiva, consideración que, igualmente, manifiestan en el preámbulo de la "Carta de rodajes" que redactaron en 2006 y en la que defienden la necesidad de equilibrar la coexistencia de los equipos fílmicos y la cotidianidad de la metrópoli

Los rodajes que enriquecen la vida artística, cultural y económica de la capital y participan plenamente de su resplandor nacional e internacional, implican, sin embargo, unas evidentes obligaciones logísticas. La actividad de los rodajes tiene, en efecto, un impacto directo sobre el espacio y el ritmo de las parisinas y los parisinos. La ciudad de París tiene como doble ambición conciliar la recepción y la promoción de las filmaciones con la preservación del modo de vida de sus habitantes. (2006: 2. Trad. M. Tovar)

Lo que se evidencia en estas líneas es que, aunque París ejerza como escenario real, natural de una creación fílmica, no puede abandonar en ese proceso de la captura cinematográfica su identidad urbana, su naturaleza de lienzo en el que desarrollan su día a día sus relaciones y conexiones aquellas personas que la habitan e, igualmente, esas otras que la visitan.

\subsection{Recorridos cinematográficos: la experiencia del parcours de Midnight in Paris}

Como se ha indicado en el epígrafe anterior, la Mairie / Ayuntamiento de París ofrece la posibilidad de revivir las situaciones desarrolladas en diversas narraciones fílmicas. Esta iniciativa ha sido desarrollada incluso por conjuntos vecinales concretos, como el de Montmartre (barrio del $18^{\text {ème}}$ ) que, ante la repercusión que tuvo Amélie (2001), decidió crear un recorrido a partir de los lugares retratados por su realizador, Jean-Pierre Jeunet, que, a día de hoy, 
sigue ofreciéndose. En el caso de las propuestas publicadas por el Ayuntamiento, el modelo es sencillo y concreto: además de incluir el póster publicitario oficial como portada del dossier, incorpora información sobre el cuerpo técnico y artístico, introducido a su vez por una sinopsis reducida y una breve presentación sobre la actividad cinematográfica de la ciudad y la labor que, conjuntamente, llevan a cabo la Mission Cinéma y la Mairie

Los recorridos de cine les invitan a conocer París, sus barrios más célebres, insólitos e históricos a través de películas emblemáticas realizadas en la capital. Cada año, París acoge más de 900 rodajes en 5.000 decorados naturales. Estos recorridos de cine son guías para todos los enamorados de París y el cine (2011: 2 Trad. M. Tovar)

Posteriormente, se presenta un mapa reducido de la urbe con una selección de las localizaciones señaladas numéricamente y que, en los párrafos consecutivos, se encuentran explicadas en términos histórico-fílmicos; es decir, se ofrecen datos sobre el espacio en sí mismo, pero también, sobre el momento de la película en la que aparecen o la relación que se plantea entre los mismos y uno o varios de los personajes. En este sentido, se ha de especificar que el número habitual de entradas es seis, por lo que es manifiesta la visión reduccionista que se aplica al análisis localizador y que, como se explica para el caso de la producción examinada, parece responder más a una potenciación de escenarios ya conocidos y, sobre todo, con cierta identidad turística que a un interés por ofrecerle al visitante y al propio habitante de la urbe nuevos recorridos regidos, únicamente, por intereses cinematográficos.

Cuando se consulta el recorrido propuesto para la narración del realizador estadounidense lo que se avista primeramente es la cercanía entre los decorados naturales, ya que, todos, salvo uno, se encuentran en zonas próximas al Sena. Esto favorece la visita del turista-espectador que puede revivir, en su mayoría, las escenas y secuencias protagonizadas por Gil (Owen Wilson) sin necesidad de desplazarse por barrios y distritos distanciados entre sí. De esta manera, los emplazamientos que constituyen el decimotercer parcours elaborado por el Ayuntamiento parisino y, de acuerdo a su orden de presentación,

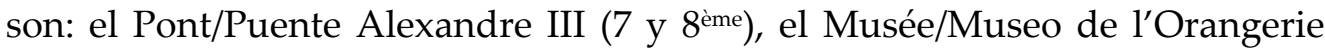
(1 $\left.{ }^{\text {er}}\right)$, el Marché aux Puces/Mercado de las Pulgas (mercadillo) de Saint-Ouen $\left(18^{\mathrm{èm}}\right)$, los bouquinistes ( $1^{\mathrm{er}}, 4,5,6$ y $\left.7^{\mathrm{ème}}\right)$, las Berges/Orillas del Sena ( ${ }^{\mathrm{er}}, 6 \mathrm{y}$ 


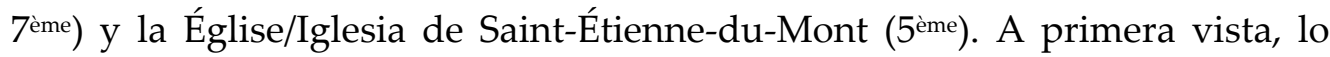
que se percibe teniendo en cuenta, únicamente, sus arrondissements (distritos) es que comparten las mismas ubicaciones; identificándose la excepción del Marché: su identidad como constituyente de uno de los más exteriores de la capital (el área de Montmartre -como Belleville o Passy, por ejemplo- tiene su origen en la comunas anexionadas en 1860 y que fueron redefinidas como distritos o barrios) implica una evidente distancia espacio-temporal entendiéndose que, al ubicarse en la zona alta y alejada del centro de la ciudad, el tiempo necesario para llegar allí es mayor que el empleado para con las restantes localizaciones. Es por ello que el análisis del parcours de Midnight in París que se desarrolla a continuación va a excluir a esta última ubicación; también porque este comentario está basado en la experiencia personal del mismo y en que esta tampoco formó parte de la visita.

Si se sigue la numeración de la propuesta enunciada líneas atrás, el punto de partida del paseo se ubica entre las dos rives (márgenes), en el puente dedicado a la alianza franco-rusa y que es donde, también, concluye la narración: siguiendo el camino que señalan Gil y Gabrielle (Léa Seydoux), la vendedora de vinilos del Marché, con la que se encuentra, se continúa en dirección Grand Palais/Gran Palacio (8 $\left.{ }^{\mathrm{èm}}\right)$. Recorriendo, como se marca en el mapa, las orillas del Sena en su margen derecha, el turista-espectador tiene que pasar por uno de los iconos parisinos, la Place de la Concorde/Plaza de la Concordia $\left(8^{\text {ème}}\right)$, y adentrarse en otro de ellos, el Jardin des Tuileries/Jardín de las Tullerías $\left(1^{\mathrm{er}}\right)$ para acceder al museo donde se encuentran Les nymphéas de Monet que Paul (Michael Sheen) explica a su esposa Carol (Nina Arianda), Inez (Rachel McAdams) y Gil. Omitiendo al número tres, que es el Mercado de las Pulgas, la siguiente localización indicada es la hilera de los bouquinistes, quienes se encuentran repartidos no sólo a ambos lados del Sena, también bordeando a la Île de la Cité/Isla de la Ciudad (4 $\left.{ }^{\mathrm{ème}}\right)$ (habitada, entre otras, por la Cathédrale/Catedral de Notre-Dame y por la Sainte-Chapelle/Santa Capi1la). Considerados Patrimonio de la Unesco desde 1992, el mismo parcours explica el origen y características de estos vendedores que, dadas sus especificidades, no encuentran traducción al castellano

Sobre las orillas del Sena, a lo largo de más de $3 \mathrm{~km}$, los 220 bouquinistes y sus 900 'cajas verde vagón' forman parte del paisaje parisino. Del Puente Marie al muelle del Louvre y del muelle de la Tournelle al Voltaire, 300.000 libros 
antiguos o contemporáneos, estampas, grabados, revistas y postales de colección componen la librería de mayores dimensiones a cielo descubierto. Desde el siglo $X V I$, los libreros extranjeros recorren los bordes del Sena para, finalmente, fijar sus 'cajas' algunos siglos después (2011: 5. Trad. M. Tovar).

Al mantenerse la lógica apuntada por la propuesta de la Mairie, el turistaespectador pasea, primeramente, por la margen derecha del río, avistando a su paso escenarios clave de la urbe como son la Place de Châtelet ( $1^{\mathrm{er}}$ y $\left.4^{\text {ème }}\right)$ o el mismo Hôtel de Ville general (4ème) ${ }^{3}$, para, una vez superada la Île de SaintLouis $\left(4^{\mathrm{èm}}\right)$, conocer los puestos bibliográficos de la parte izquierda. En este sentido se quiere hacer hincapié en la señalización del mismo recorrido y donde las líneas rojas se dividen en dos trazos que, además de orientarle hacia la misma porción urbana, le especifican que puede pasar al otro lado de la ciudad por dos vías diferentes: la sucesión Pont Louis-Philippe - Quai de l'Archeveché o la continuidad residente entre los Puentes Marie y de la Tournelle (todos ellos enlazando los distritos $\mathrm{n}^{\mathrm{o}} 4$ y 5), en función del mayor o menor grado de interés que tenga en conocer las instalaciones de los bouquinistes.

Siguiendo en la margen izquierda, el turista-espectador se encuentra con la penúltima localización para la que, sin embargo, necesita acceder y descender al nivel inferior de la Île de la Cité: les berges del Sena; emplazamiento donde, pasada la medianoche, Gil, acompañado de Adriana (Marion Cotillard), se encuentra con Zelda Fitzgerald (Alison Pill). Sin embargo, aunque la ubicación del escenario es precisa en términos de distritos, no lo es el punto exacto al que señala la flecha del panfleto, ya que, la escena fue rodada en el lado derecho y no en el izquierdo, detalle apreciable en la imagen incluida en el parcours, en la visita personal de la localización y en la revisión de la cinta [50:58-51:07] ${ }^{4}$ cuyo plano, presentando en primer término al Pont Neuf ( $1^{\text {er }} y$ $6^{\text {ème) }}$, permite la visualización de la punta de la isla pasado uno de sus arcos, uno de los árboles que la habita $\mathrm{y}$, aunque poco definidos, los pilares del puente próximo: el Pont des Arts (1 $1^{\text {er }}$ y $\left.6^{\text {ème}}\right)$.

\footnotetext{
${ }^{3}$ Sujetos a la dimensión, distribución y configuración histórica de la metrópoli, cada uno de los distritos ostenta su propio Ayuntamiento.

${ }^{4}$ Las referencias numéricas de la forma $[\mathrm{XX}: \mathrm{XX}]$ remiten al minutaje de la película correspondientes a la edición consultada y cuyas referencias aparecen en la Bibliografía.
} 


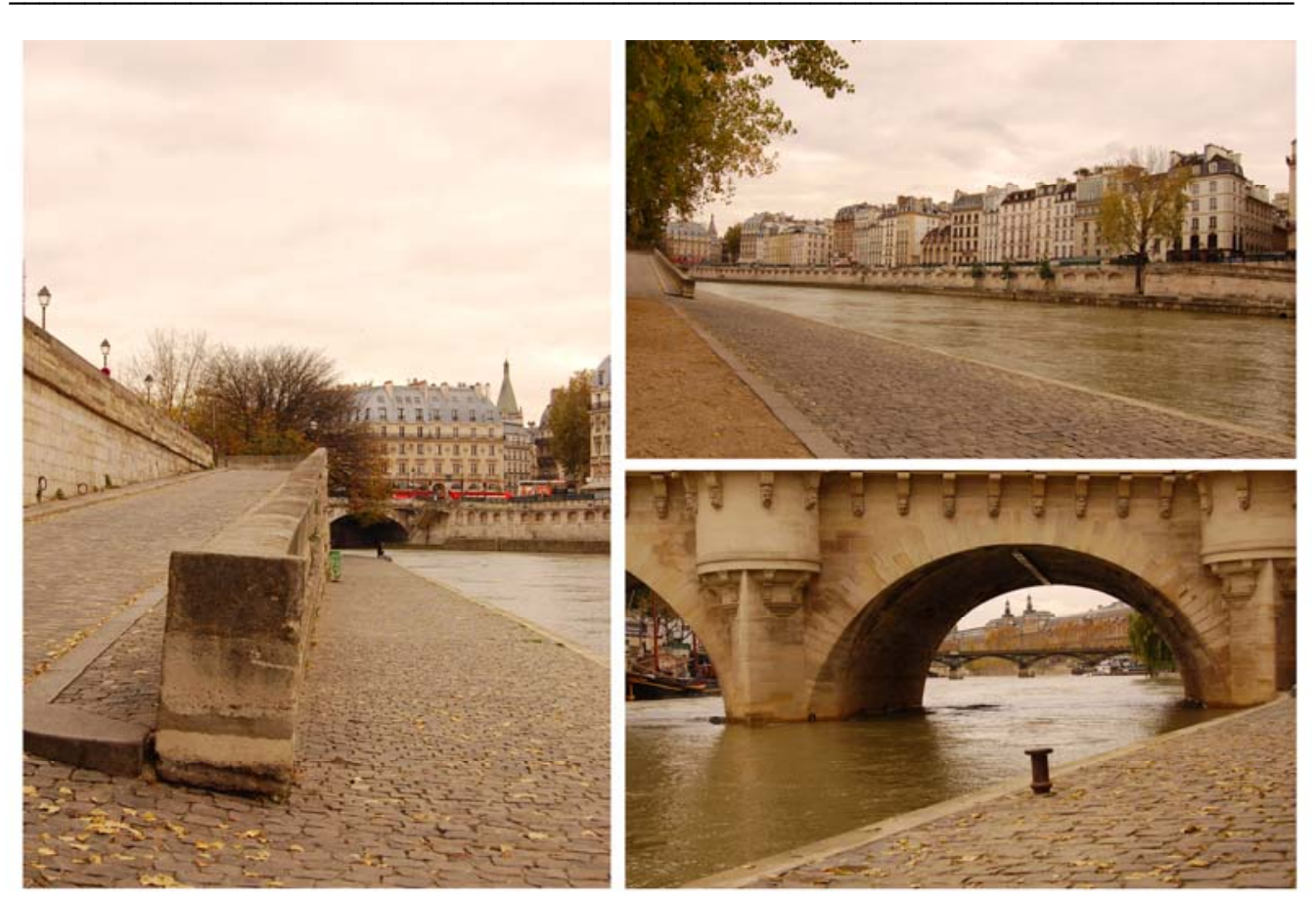

Fig. 1- Les berges del Sena: localizaciones del film e imagen de fondo del póster publicitario. Foto M. Tovar.

Entre los motivos que explican esta modificación enunciativa se reitera el ya nombrado de trasladar al turista-espectador a aquellos otros escenarios que, a pesar de no respetar la identidad fílmica específica, sí lo hacen con respecto a otras películas siendo, del mismo modo, fundamentales para la constitución de la metrópoli y a lo que se suma la lógica de la distribución de los números que conforman el parcours y que responden al principio de máxima proximidad entre ellos.

La decimotercera propuesta fílmico-turística de la Mairie concluye en uno de los barrios de la margen izquierda más emblemáticos, el Latino o Quartier Latin (5 y $\left.6^{\mathrm{èm}}\right)$, y en las inmediaciones de uno de los iconos parisinos por excelencia: el Panthéon (5 $\left.{ }^{\text {ème}}\right)$. Es en su parte izquierda trasera donde se posiciona la Iglesia de Saint-Étienne-du-Mont y de la que, únicamente, se presentan sus escaleras del lado, nuevamente, izquierdo y que permiten la visualización de la Rue de la Montaigne de Sainte-Geneviève (5 $\left.5^{\text {ème}}\right)$ y de la calle homónima al del centro religioso, siendo a través de la primera por la que accede el au- 
tomóvil de época al que se sube Gil para retroceder en el tiempo. Este último emplazamiento del parcours es, posiblemente, el que ostenta mayores repercusiones positivas, gracias no sólo a su presencia en la narración de Allen, sino también a que ha sido una de las imágenes empleadas en los diferentes productos promocionales. Ubicada, como se ha comentado, en los aledaños de la construcción que originariamente iba a ser un templo dedicado a Santa Genoveva y hoy alberga los cuerpos de los grandes nombres de la patria francesa, el Panteón, la Église ha mantenido a lo largo del tiempo un rol secundario explicado por esa presencia, punto neurálgico turístico de la zona junto al Jardín de Luxemburgo (6 $\left.{ }^{\mathrm{èm}}\right)$ (ubicado justo enfrente, al final de la Rue Soufflot) y que comparte protagonismo con la Université de la Sorbonne (5 ème), cuyos diferentes centros y facultades se encuentran repartidos por las calles colindantes. Sin embargo, como ya se ha indicado antes, Midnight in Paris la ha erigido a la misma posición dotándola de un atractivo especial para el turista-espectador; demostración de cómo el séptimo arte participa activamente de la configuración de la urbe desde una perspectiva identificativa de sus principales puntos de interés, si bien la Iglesia se ha visto desprendida, en cierta forma, de uno de sus elementos constituyentes que, dado el empleo cinematográfico comentado, ha asumido una nueva identidad independiente ejerciendo como atractivo, en primera instancia, de sí mismo, pero, consecutivamente, del propio diseño arquitectónico del que depende.

El examen del parcours de Midnight in Paris alumbra un doble resultado sujeto a un mismo objetivo: el primero es que la selección de los emplazamientos es aleatoria. Con esto lo que se propone es que, en lugar de posicionar los diferentes números en aquellas localizaciones que ocupan la imagen durante un mayor número de tiempo, se reiteran o actúan como soporte escenográfico de momentos narrativos claves para el desarrollo del discurso fílmico, los sitúa en arquitecturas emblemáticas e iconos de la urbe (a excepción de la Église). El segundo deriva de su estado e identidad: todos ellos, salvo el Musée, son escenarios abiertos, de acceso público. De esta manera, aunque se siga la ruta más sencilla y se cumpla con la secuencia planteada por la Mairie, es inevitable, al menos, visualizar durante su ejecución a otros referentes parisi-

${ }^{5}$ El enfoque aplicado dificulta bastante su identificación, así como que en ningún momento el plano sea lo suficientemente amplio como para reconocer el elemento arquitectónico al que permite acceso. 
nos por excelencia. Esto arroja una consideración a tener en cuenta con respecto a la distribución de la metrópoli: si se observa el plano incluido en el folleto, se reconocen los principales atractivos turísticos a la par que constituyentes y determinantes de la capital gala. Recuperando parte de su Historia, es innegable la repercusión que la reforma haussmanniana tuvo para con esta proximidad, cuanto menos, visual: centrado en la búsqueda de una ciudad más operativa, que facilitara el transporte de sus habitantes y que reforzara el prestigio y la enunciación de sus construcciones más emblemáticas, el barón Haussmann convirtió a París en un entramado en el que las avenidas, los bulevares y los trazados regulares son sus principales distintivos. Esa apertura explica, por ejemplo, que desde la Place de la Madeleine (8 $\left.{ }^{\text {ème}}\right)$, en concreto desde la fachada principal de la iglesia que la habita, se vean el obelisco de la Place de la Concorde y la Assemblée Nationale (7ème); percibiéndose lo mismo para el caso de la recién indicada plaza y desde la que se vislumbran el Arc de Triomphe ( $\left.8^{\mathrm{èm}}\right)$, las Tullerías, el Museo del Louvre (1er), la también citada Place de la Madeleine e, incluso, una porción de la parte superior de la Torre Eiffel (7ème). Con este planteamiento se defiende que, más allá de recolectar aquellas localizaciones consideradas como representativas de la ciudad y que han sido incluidas en una película determinada, los parcours del Ayuntamiento de París potencian la visita del corpus urbano en su totalidad. Para este caso concreto y como se ha puntualizado en el fragmento dedicado a cada una de las numeraciones, establecer el recorrido de acuerdo a la propia margen del río implica ya un acercamiento a esos otros iconos que, en otras ocasiones, también han actuado como escenarios cinematográficos. Recae, por tanto, en el turista-espectador la decisión de cumplir sin modificación el paseo ofertado o variarlo según su posicionamiento con respecto a esos otros recursos vecinos.

\section{Woody Allen: un cineasta europeo con una mirada...}

En el segundo punto de este artículo se profundiza en el tratamiento que el cineasta norteamericano le da a París en la película objeto de análisis. El título abierto del mismo responde a la incógnita subyacente en el tráiler y en los materiales promocionales; información que, de acuerdo a su naturaleza, resume la idea genérica del discurso fílmico dejando ocultos, por el contrario, detalles que participan y determinan la significación e interpretación del relato. De este modo, la primera aproximación a Midnight in Paris potencia la 
creencia de que el largometraje es más una suma de clichés que el reflejo de una mirada personal; valoración también manifestada por Diane Lisarelli en su artículo Paris a mauvaise Allen (2011) publicado en la revista francesa Les Inrocks y quien, igualmente, incide en lo estereotípico predominante durante gran parte del tráiler comercializado:

Poco cerebro, pero mucho acordeón en el tráiler de Woody Allen, quien parece estar decidido a aumentar el nivel de los clichés. Además del instrumento emblemático de Yvette Horner, identificamos según su orden, en 2 minutos y 1 segundo: Giverny y sus nenúfares, una bolsa de Dior, el museo Rodin, Carla Bruni-Sarkozy, vino tinto degustado en una terraza con vistas a la Torre Eiffel, los Campos Elíseos de noche, el metro aéreo, los pavimentos (las aceras), un carrusel y un anciano bigotudo que empuja a un diablo con un utensilio grueso hacia arriba (Lisarelli, 2011. Trad. M. Tovar).

Sin embargo, esta tendencia a aglutinar lo arquitectónicamente más icónico de la capital ya hizo acto de presencia en el otro film que Allen rodó, aunque no íntegramente, en París: Todos dicen I love you (1996) y en cuyo tráiler oficial se suceden las cúpulas de la basílica del Sacré-Cœur (18ème), los Campos Elíseos (8 $\left.{ }^{\mathrm{èm}}\right)$ y la Place de la Concorde. El director norteamericano se aproxima, por ende, a la visión aplicada por la mayoría de autores cinematográficos y realizadores que han trabajado en el marco hollywoodiense: a pesar de entender al escenario urbano parisino en toda su extensión, lo que explica el posicionamiento de la cámara en localizaciones múltiples (tanto en términos históricos como estructurales -arrondissements-) y residiendo en ese ejercicio un distanciamiento de lo estereotípico, acaban cediendo minutos de manifestación a lo icónico y emblemático variando su totalidad, generalmente, en función de los rasgos estilísticos, relativos al género narrativo y a las propias características de quien firma la pieza audiovisual.

\subsection{Títulos de crédito iniciales: una oda a lo turística y típicamente parisino.}

Al igual que sucede con el fragmento promocional, los primeros cuatro minutos del film no quedan exentos de la presencia de lo parisino reconocible; por el contrario, el muestrario resultante es parcial al trabajarse con imágenes en las que la enunciación de lo identificable es compartida: los planos son abiertos, por lo que esos elementos asumen una identidad constitutiva y 
equiparada a la de aquellos otros escenarios que, también, son fundamentos estructurales de la metrópoli. Como si de un retrato que acapara las 24 horas de cualquier día en la capital francesa se tratara, Allen pasea su cámara por varios distritos obteniendo una secuencia expositiva sustentada en la alternancia turístico/reconocible-cotidiano: de los 60 planos que suponen los tres primeros minutos del discurso, 36 se corresponden con áreas urbanas de naturaleza mixta. Se recurre a este concepto porque son desconocidas para la figura genérica del turista-espectador, pero no lo son ni para sus habitantes, ni tampoco para aquellos que por diversos motivos las conocen con mayor detalle. Ejemplificaciones de ello son los planos con los minutajes [00:51] y [01:29] y en los cuales se muestran las aceras de los Campos Elíseos; también el ubicado en el [01:12] donde los extras suben unas de las escaleras que se encuentran en las cercanías del Sacré-Cœur o, incluso, la floristería que aparece en el [01:19] y que se localiza en el Quai de la Mégisserie, próximo al Hôtel de Ville. Asimismo, en esta sucesión espacial se reconocen varios aspectos relevantes: el primero, la redundancia enunciativa de la Plaza de la Concordia, ya sea expresa o posicionalmente, al aparecer en un total de cinco ocasiones capturándose desde ella dos de los planos. Otro índice presencial elevado se reconoce para el caso de la Torre Eiffel que forma parte de la imagen cuatro veces, si bien, en algunas de ellas (casos en los que el "Café du Trocadéro" aparece en primera instancia), son pequeños fragmentos de su estructura los que la denotan. En un nivel enunciativo similar se ubica el Arc de Triomphe que llega a ser referido hasta en tres encuadres distintos.

El segundo de los detalles compositivos que llama la atención es la aglutinación espacial: el cineasta norteamericano se sirve del montaje para dotar de variedad a una sucesión de capturas urbanas que son coincidentes en ocho distritos de los 20 que constituyen la capital gala. De esta manera, el 1 ${ }^{\mathrm{er}}$, el $8^{\text {ème }}$, el $16^{\text {ème }} \mathrm{y}$ el $18^{\text {ème }}$ son los más repetidos tanto por contener a los emblemas presentados líneas más arriba como a algunos de los escenarios cotidianos; junto a ellos, el $4^{\text {ème }}$ y el $5^{\text {ème }}$ mostrando el primero desde el Quai d'Orléans a Notre-Dame y el segundo enunciando al Pont de l'Archeveché mediante el señalizador ubicado en el semáforo del cruce que le da acceso. De forma referencial también se incluye en esta lista al 7ème, arrondissement habitado, entre otros, por la Asamblea Nacional y donde se piensa que, posiblemente, se han rodado los planos que contienen a la Tour vista desde calles 
desconocidas. Finalmente, el octavo distrito que forma parte de los créditos iniciales es el número $6 \mathrm{y}$, a diferencia de los anteriores, es al que se le atribuye el calificativo de "desconocido", puesto que los planos rodados en sus inmediaciones no contienen a ninguno de sus edificios más emblemáticos. Allen deambula por los alrededores de la Plaza Henri Mondor y del Bulevar de Saint-Germain grabando con su cámara la entrada de los cines "UGC Danton" [02:36], la Rue de l'Ancienne Comédie (que se encuentra en el lado opuesto) [02:46] y el Cour du Commerce Saint-André, una galería conectora de dos calles y donde se ubican negocios de diferentes características [02:50].

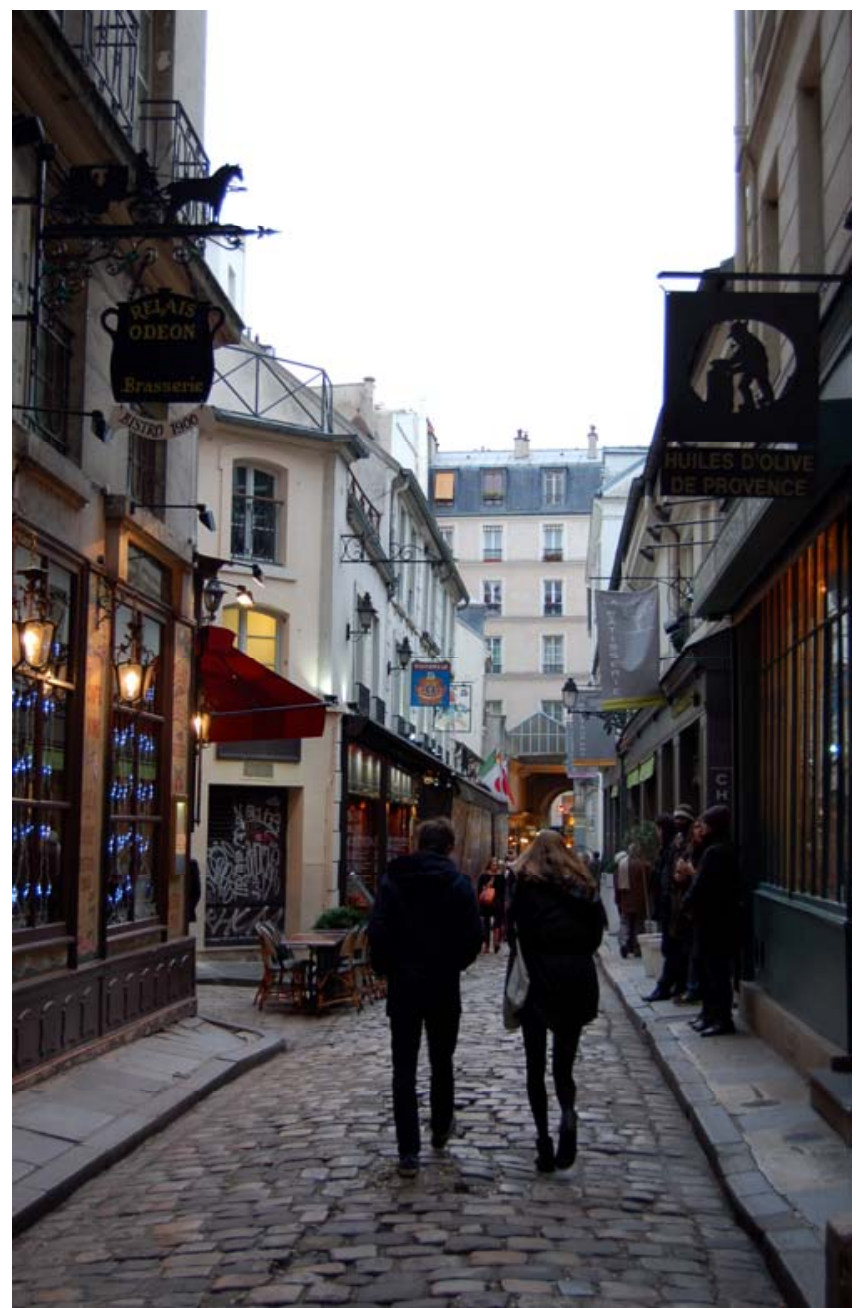

Fig. 2 - Cour du Commerce Saint-André en noviembre de 2013. Foto M. Tovar. 
Esta última, inaugurada en el siglo XVIII, es una de las muestras más evidentes del interés del director norteamericano por adentrarse en aquellos lugares propiamente parisinos y que suelen pasar desapercibidos para gran parte de los turistas-espectadores (su acceso no es tan perceptible como el de la mayoría de los patios comerciales repartidos por el entramado urbano); ejemplo que, en cierta medida, contradice las palabras del neoyorquino quien, en una entrevista ofrecida al diario El País en 2012, reconocía su práctica fotográfica cuando se enfrenta a una metrópoli europea y cómo la misma se deriva de su condición de habitante episódico y que recala en el aglutinamiento de los clichés: No tengo conocimiento real de esas ciudades (...). En Europa soy estrictamente un turista, y tengo la percepción de un turista. Posteriormente, y ubicándose en los límites del distrito $\mathrm{n}^{\mathrm{o}}$ 6, el cineasta cambia de Boulevard trasladándose al de Saint-Michel, del que toma como localizaciones al bistrot/brasserie "Saint-André" y a la Place Saint-Michel, que supone el contraplano del primero [02:56-03:03]. A pesar de ser una de las plazas más relevantes de la urbe, no es mostrada desde una perspectiva habitual negando, consecuentemente, la presencia de la fuente de nombre homónimo y que es su principal distintivo. De esta manera, y aún rodando en una de las áreas más turísticas de París, Allen dota de naturaleza mixta a esos dos escenarios, ya que sólo son reconocibles para aquellas personas que tienen un cierto manejo constitutivo y conceptual de la metrópoli.

El tercer aspecto mencionable es que los arrondissements identificados son los mismos que los del parcours, exceptuando al 16 ème, que se suma en este segundo caso. Coincidencia valorable en términos reduccionistas y asociados a la tendencia dominante que, según Kristian Feigelson, se aplica a la capital gala cuando es interpretada desde la lingüística y técnicas cinematográficas:

Esta ciudad reconstruida, sino deconstruida, deviene para un numeroso grupo de realizadores un puro objeto estético; imposible de encuadrarse en su globalidad, se esfuerzan por captar el movimiento. Se convierte en la trama adulada de una historia más secuencial. Es, en definitiva, el lugar donde convergen las diferentes crisis de la representación. En estas perpetuas reconfiguraciones, la ciudad en el cine aparece como un modelo desorientado, atípico, a fin de cuentas, inclasificable. (2007:110. Trad. M. Tovar). 
Esa deconstrucción señalada por el autor citado puede ser abordada desde una óptica positiva, pero, igualmente, desde su inversa: la primera se aplica a partir de la consideración de que, al eliminar referencialmente a los distritos restantes, el número de iconos se ve consecuentemente reducido (negándose, entre otras, las presencias de las estaciones ferroviarias del norte -10 ème- o las plazas de Bastilla -4, 11 y 12 ème- y la República -3, 10 y 11 ème-, todos decorados naturales manifestados en relatos fílmicos). Por contra, la aproximación negativa se expresa en la redundancia de los referentes arquitectónicos enunciados y que conlleva no sólo a una disminución existencial de la urbe, quedando reducida a esos compartimentos estancos que la integran, también al establecimiento de una identidad sujeta a lo emblemático. Con esto lo que se quiere decir es que, con la selección y muestra de esas localizaciones se entiende a París como una metrópoli en la que la Place de la Concorde parece ejercer como su centro neurálgico siendo los escenarios que se avistan desde ella o aquellos ubicados en los alrededores sus demás integrantes. La continua alusión a esos espacios les dota de una relevancia que es asumida, especialmente, por el turista-espectador como lo esencial de la ciudad y que, de acuerdo a la información proyectada en el recorrido de la Mairie, es por lo que debe deambular al asociarlo con lo obligatoriamente visitable.

\subsection{La urbe en el tiempo presente: París lujo, París icónico, París turístico.}

Como se desprende de la referencia periodística incluida más arriba, Woody Allen ofrece una imagen de la capital francesa derivada del estatus social de la familia protagonista. Consecuentemente, los emplazamientos en los que se les presenta responden a esa característica como a su naturaleza de visitantes. El análisis de las localizaciones del tiempo narrativo presente produce los siguientes resultados: las localizaciones turísticas, habitualmente incluidas en las guías de visita, se enuncian en nueve ocasiones frente a las cinco de los lugares asociados al lujo y al poder económico. Ahora bien, estas cifras son entendidas en cuanto a entidades y no a número de representaciones, como se explica en las siguientes líneas.

Excluyendo al fragmento rodado en los jardines de Giverny dado que su distancia con respecto al centro parisino es mayor a la del caso que se expone, la primera visita de Gil e Inez es realizada conjuntamente con la pareja formada por Paul y Carol siendo el destino los jardines de Versailles [09:07], a 
unos 20 minutos de la capital en automóvil y conectados a través de la línea $C$ de su sistema de trenes de cercanías (RER). La cámara regresa allí durante los últimos minutos de la narración grabando en el interior de una las salas palaciegas más destacadas: la Galería de los Espejos o Gran Galería, y a la que precede en el montaje uno de los aposentos reales con los que está conectada [1:25:53]. Manteniendo la tendencia museística, el mismo grupo de personajes es presentado, posteriormente, en los jardines del Musée Rodin (7̀me), concretamente en el área donde se posiciona, nuevamente y como en el caso anterior, uno de sus distintivos más característicos: la escultura El Pensador [12:41]. Tendencia reiterativa, la historia regresa a este museo, si bien durante un menor porcentaje de tiempo en el [57:18]. La duplicidad enunciativa y espacial se presenta, también, con el ya citado Mercado de las Pulgas: mientras que la primera visita es efectuada por Gil, Inez y la madre de esta [40:28], la segunda solo lo es por el primero [1:01:36]. Precisamente, es la primera secuencia filmada en el mercado del $18^{\text {ème }}$ la que da paso al segundo museo visitado por las dos parejas expuestas y que ha sido previamente indicado: el de l'Orangerie [42:42]. Reside aquí un aspecto importante en cuanto a las localizaciones turísticas y es que no siempre son mostradas exteriormente. En otras ocasiones, su presencia es reducida al incorporarlas a planos habitados por más integrantes urbanos (como se ha puntualizado para el caso de los títulos de crédito), pero, suele dejarse entrever algún rasgo que, generalmente, para el turista-espectador con un cierto bagaje sobre la urbe, puede identificarlos. Con esto lo que se quiere decir es que los diálogos, como sucede en este fragmento, se erigen como recursos referenciales clave para la inclusión de esos espacios icónicos y asociados a la ville lumière, siendo alusiones genéricas (nombre/denominación), visuales (como el plano de Le penseur en su segunda aparición) o compositivas (caso del museo situado en las Tullerías y del que Inez especifica que posee las obras de Monet $)^{6}$.

La siguiente selección espacial catalogada como turística aparece, como la anterior, en el parcours: sumándose a los muelles del Sena próximos al Pont

\footnotetext{
${ }^{6} \mathrm{Si}$ bien se trata de una valoración subjetiva, se considera que, siendo notable la multiplicidad de obras y corrientes plásticas y artísticas congregadas en las diferentes instituciones museísticas, galerías y salas parisinas, la presencia de la obra de este autor en la película no es casual, al ser específica del tiempo narrativo pasado (Les nymphéas/Los nenúfares son el resultado de un trabajo continuado entre 1914 y 1926, como explican en la página web de l'Orangerie).
} 
Neuf ya analizados, Gil pasea por los próximos a Notre-Dame, concretamente, por los de la Tournelle. Además de aparecer incluidos en el folleto del Ayuntamiento, el plano concede un pequeño margen de expresión a la catedral de la Île-de-la-Cité que asoma por la esquina superior derecha [1:02:30], parte trasera a la que se traslada posteriormente el protagonista masculino. La Place Jean XXIII (4 $\left.{ }^{\text {ème}}\right)$, contigua en el marco urbano, acoge una secuencia en la que esa porción de uno de los referentes arquitectónicos prototípicos de la ciudad de la luz se manifiesta en toda su dimensión negando a esa otra, la que da acceso al interior del centro religioso y que es la más explotada promocional y turísticamente [1:03:07]. Aunque su popularidad se ha magnificado hace escasos años, ShakespeareECompany (5 ${ }^{\text {ème}}$ ) es uno de los reclamos más evidentes del área ocupada por la Cathédral, en parte, potenciado por su presencia en otras narraciones cinematográficas como Antes del atardecer (Richard Linklater, 2004). Esta librería dedicada, especialmente, a la literatura inglesa justifica su presencia por la práctica profesional de Gil, guionista hollywoodiense, quien la visita durante los últimos minutos del discurso fílmico [1:26:34]. En esta ocasión, se identifica un principio más de guía turística que de relevancia narrativa, porque, si en todas las localizaciones anteriores se produce algún acontecimiento que determina el desarrollo de la película $u$ ofrece una información histórico-artística como se considera para el caso de las obras de Monet, en este último caso sólo se ve al personaje saliendo de la tienda, interpretándose como un guiño del cineasta a los turistas-espectadores $\mathrm{y}$, por ende, al propio negocio dotándole de un mayor interés como atractivo comercial y de visita del que ya posee.

Las dos últimas localizaciones turísticas suponen una clausura para la obra de Allen en términos espaciales que, al mismo tiempo, conlleva una repetición: mostrada de noche y haciendo gala del espectáculo luminoso que se celebra cada hora en punto, la Tour Eiffel hace acto de presencia en el centro de un plano [1:26:48] en el que el resto de componentes no es identificable como consecuencia de las características lumínicas de la nocturnidad (el reiterado sonido de las campanas, la señal que marca la introducción de Gil en los años 20, puntualiza que es medianoche). La siguiente imagen, encargada de cerrar el relato, muestra a Gil paseando por el Pont Alexandre III [1:26:55] y yendo

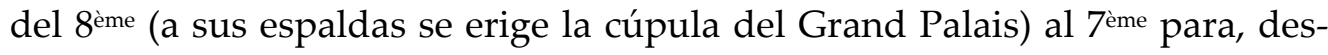
pués, retroceder en sus pasos al coincidir con Gabrielle. 


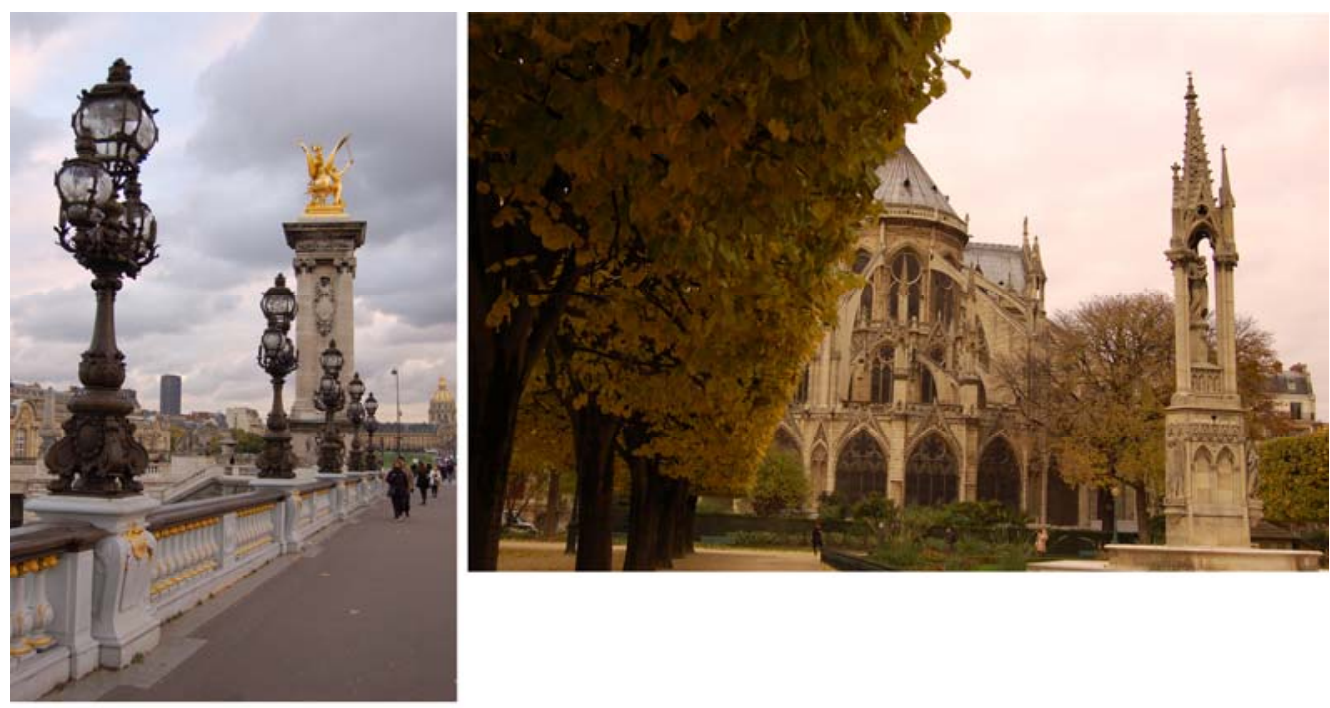

Fig. 3 (izq.) El Pont Alexandre III orientado hacia el 7ème con la Tour Montparnasse y Les Invalides de fondo. Fig. 4 (drch.) Parte trasera de la Cathédral de Notre-Dame vista desde la Place Jean XXIII.

Como previamente se ha remarcado, el número de espacios poseedores del calificativo "turístico" es mayor al de aquellos asociados al lujo en cuanto a identidades, puesto que estos últimos, como se detalla a continuación, también practican la redundancia enunciativa y presencial ampliando su número total de planos. La primera localización en la que se presenta a la protagonista y a su madre es la joyería "Chopard" [12:05], ubicada en la Place Vendôme $\left(1^{\mathrm{er}}\right)$, emplazamiento que, junto a la Rue de la Paix, una de las calles que salen de ella, aglutina a una gran parte de las marcas de moda y lujo francesas e internacionales más importantes y que es identificable gracias a la base de la columna que ocupa su centro y que se presenta según avanza la pareja de personajes por el espacio. Una cata de vinos es la excusa que reúne a todos los personajes relevantes del tiempo presente en la terraza del Hôtel "Le Meurice" [14:17], ubicado en la Rue Rivoli (1 $\left.{ }^{\mathrm{er}}\right)$. Inicialmente con el Louvre y la noria que suele ubicarse en las Tuileries de fondo, el movimiento de la cámara muestra progresivamente (y siempre en ese segundo plano) a otros de los iconos parisinos: la Tour Montparnasse (15 $5^{\text {ème}), ~ e l ~ M u s e o ~ d ' O r s a y ~(7 e ̀ m e), ~ L o s ~}$ Inválidos (ibídem) y la Torre Eiffel. Esta secuencia supone la recuperación de un postulado incluido líneas más arriba y que es la proximidad entre lo asociado y promocionado como emblemáticamente parisino, favorecido, al mis- 
mo tiempo, por la altura desde la que está captada la imagen y que reduce las distancias reales entre ellos. Minutos después, en el [17:57], el espectador descubre en qué hotel se hospedan Gil, Inez y los padres de esta al preguntar el escritor a una pareja de viandantes por el "Bristol". Ubicado en el distrito número 8, este establecimiento catalogado con cinco estrellas abrió sus puertas en 1925 en pleno corazón de los años 'folles' (locos), que vieron triunfar a Joséphine Baker, Sydney Bechet y el Charleston, como señalan en su página web; época en la que también identifican la llegada a la urbe de nombres asociados a la moda y a la cultura como Balenciaga, Picasso o Dalí. Dadas las coincidencias con el relato de Allen donde la banda sonora está constituida por temas interpretados o del género señalados y los dos artistas plásticos aparecen como personajes del tiempo narrativo pasado, se entiende que, más allá de la tradición del cineasta quien, habitualmente, se hospeda en este mítico recinto hotelero, hay una explicación cronológica que remite a la obsesión de Gil por los años 20 y que justifica la presencia de muchos de estos escenarios. Asimismo, se debe concretar que el Hôtel es una de las ejemplificaciones de cómo la enunciación de un solo emplazamiento puede influir en la representación global de un ítem espacial, ya que, aunque es una única identidad, su reiteración en pantalla es continua ${ }^{7}$ remarcando, al mismo tiempo, el poder económico de las personas que se alojan en él (los diferentes planos descubren el lujo residente en las salas o los servicios que prestan) y autocitándose a través de diferentes medios (como el nombre bordado en el albornoz).

La cuarta localización asociada al poder monetario es un anticuario al que acuden Inez, su madre y Gil [30:13]. Sin embargo, en esta ocasión su ubicación no es posible, ya que no se dispone de detalle alguno para, al menos, localizarla en un distrito de forma genérica. Sucede lo contrario con el quinto caso: el personaje interpretado por McAdams y sus padres disfrutan de una cena en el restaurante "Alain Ducasse" [44:46], concretamente, en el establecimiento que tienen en "Le Meurice", el hotel identificado como segunda entidad de naturaleza lujosa.

Dado que la mayoría de los escenarios urbanos turísticos ya han sido abordados con anterioridad, no se puede obviar el hecho de que, nuevamen-

\footnotetext{
${ }^{7}$ Aparece un total de seis veces: cuatro son escenas interiores rodadas en la habitación de Inez y Gil ([28:50], [56:31] [1:04:43] y [1:22:46]) y dos exteriores ([39:59] y [1:00:38]).
} 
te, este análisis expone la concentración espacial que Allen aplica a su largometraje de 2011: más numeroso para el caso de las unidades del primer grupo, el asociado al poder económico destaca porque todas las localizaciones (a excepción del anticuario) se ubican en el primer y octavo arrondissements, aspecto comprensible si se tiene en cuenta que son estas dos áreas las que concentran una mayor actividad comercial de similares características reconociéndose incluso en el segundo de ellos al denominado "Triángulo de oro".

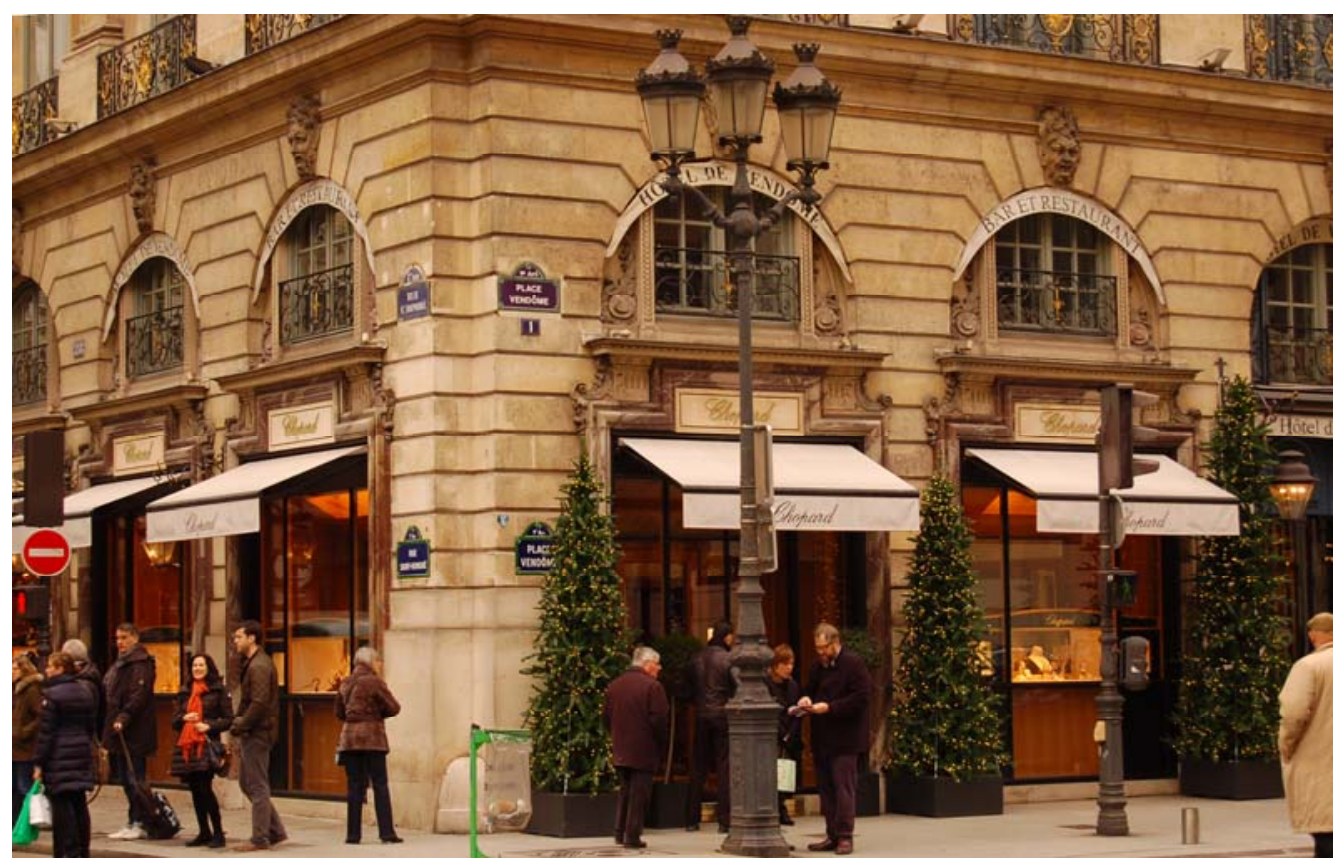

Fig. 5 - La tienda de Chopard en Place Vendôme. Primer referente del París lujoso (Foto M. Tovar)

Este reduccionismo aplicativo implica, como se ha defendido, una disminución interpretativa para el marco urbano por parte del turista-espectador; pérdida de la noción espacial también reconocida por Fabio La Rocca):

La mirada cinematográfica posee una potencialidad imaginaria que influye y forma nuestro pensamiento y nuestras maneras de aprehender, así como se erige, en la práctica, como una referencia para la arquitectura, los urbanistas, los paisajistas que se inspiran en este imaginario. La ciudad en el cine es como un 'trayecto antropológico' (G. Durand); y en ese trayecto se ofrece un territorio que hay que explorar y en el que se pueden experimentar y verificar los códigos 
de la reproducción visual que tienden hacia una sinfonía, una fluidez del espacio-tiempo, la simbología y lo cotidiano (La Rocca, 2005. Trad. M. Tovar).

Si bien el imaginario propuesto por Allen se altera después de los minutos iniciales y donde la perspectiva metropolitana es más amplia en cuanto a que retrata un mayor número de emplazamientos (aunque coincidentes en unos distritos específicos), la reiteración de los casos expuestos se ve complementada por la presentación de los asociados a los años 20 y que, como se examina en el siguiente apartado, reconocen una omisión de su identidad presente.

\subsection{El París de los años 20: la negación de una época en la metrópoli actual.}

Mientras que la capital gala del tiempo narrativo presente queda ligada, en su fundamento, a lo turístico, su precedente es calificada por el director bajo el principio de negación siendo uno de los principales problemas que se afrontan cuando se desea ubicar a las localizaciones catalogadas como propias de los años 20 que varias de ellas carecen de distintivo alguno que lo permita. La primera incursión de Gil en su época soñada se produce en el [18:38], cuando Allen ya ha realizado esa muestra turística y con reminiscencias en las imágenes postales que acaparan el fragmento anterior. Aún emplazando al personaje de Owen Wilson en la iglesia de Saint-Étienne-du-Mont, única referencia al pasado que recogen la mayoría de los trabajos que proponen rutas y visitas asociadas al largometraje (la relativa a los muelles se entiende como de naturaleza mixta, de acuerdo a lo que se concluye en las últimas líneas), es imposible hacer lo mismo con la casa a la que se traslada [19:49]. Únicamente una de las referencias consultadas la identifica: el sitio web "Movie Locations", dedicado a estudiar urbanística y cinematográficamente a las ciudades retratadas en el séptimo arte. Así, en la entrada dedicada a Midnight in Paris determina que el punto de llegada del primer trayecto de

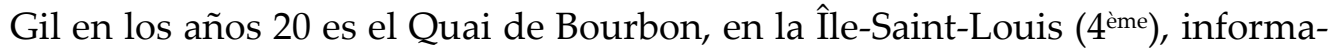
ción que se verifica si se introduce esta dirección en el buscador de Maps.Google y que, del mismo modo, permite demarcarlo exactamente al identificar en su número 53 el portal en el que se para el vehículo en el que viajan los personajes. La realidad del París conservador de calles con pendiente, de un solo carril y opuestas, tanto estética como dimensionalmente, a los grandes bulevares y avenidas derivados de la reforma haussmaniana hace acto de presencia en el minuto [23:01] cuando el protagonista, acompañado de 
los Fitzgerald, se traslada a otra fiesta. Nuevamente es la página de Internet especificada la que despeja la incógnita del área en el que la escena ha sido filmada: comunicando que se trata de la Rue Malebranche ( $\left.5^{\mathrm{èm}}\right)$; a escasos metros de la Église y que redunda en la acotación de los distritos que orienta la selección de los emplazamientos en el trabajo del cineasta neoyorquino. Aunque luego se presenta a los personajes en otro evento festivo, reside en la localización posterior el primer caso de negación de la existencia presente: mostrándose el nombre del establecimiento, el bar y bodegas "Polidor" [24:13], situado en el arrondissement número 6 y donde Gil coincide con Ernest Hemingway (Corey Stoll) acompañado de los Fitzgerald. Después de salir del establecimiento y cuya fachada es mostrada, el protagonista regresa descubriendo que ya no existe y que en la realidad es una lavandería [28:11]. Esta modificación es llamativa por un doble motivo: "Polidor" se mantiene hoy día conservando su diseño y ubicación originales, habiendo sido clientes habituales autores como Victor Hugo, Rimbaud, Verlaine o Hemingway, como se retrata en la película. Se presenta, en consecuencia, una de las conclusiones de este artículo y que es la imposibilidad de aceptación de que un escenario con repercusiones culturales y sociales históricas, testigo de la propia evolución artística vivida por la capital francesa, se mantenga en la constitución e identidad urbanas contemporáneas. Frente a los casos anteriores, la casa de Gertrud Stein a la que acude Gil acompañado de Hemingway en su segunda inmersión en los años 20 no es ubicable [33:23]. Si bien "Movie Locations" y la selección ofrecida por "Paris Perfect" en Maps.Google ${ }^{8}$ coinciden en ubicar a la galería de la norteamericana en el no 27 de la Rue de Fleurus (6 $\left.6^{\mathrm{èm}}\right)$ y en cuya fachada una placa se encarga de recordarlo, las diferencias de diseño entre la puerta real y la mostrada en la ficción niegan el rodaje en esa dirección.

La tercera noche de Gil rodeado de las figuras literarias y artísticas más relevantes de la década de los 20 supone la ubicación de la cámara en una sala que posee un tiovivo [46:04]. Nuevamente compleja su ubicación, sobre todo, por la posibilidad de que se trate de un decorado, las fuentes consultadas revelan que se trata del Musée des Arts Forains/Artes Feriantes ubicado en la zona de Bercy $\left(12^{\text {ème}}\right)$, primera salida de Allen de sus distritos de cabecera y

" "Paris Perfect's Midnight in Paris Tour" https://maps.google.com/maps/ms?msid=21598620 5709822110043.0004afc2d03f914e69429\&msa=0 
segunda en una de las áreas anexionadas a la metrópoli original en 1860. La discontinuidad espacial urbana hace acto de presencia cuando Gil y Adriana, buscando un sitio más tranquilo, son mostrados en la Place Dauphine $\left(1^{\mathrm{er}}\right)$ [48:56], a escasos metros del Pont Neuf. Ante la petición del protagonista de querer pasear por París, el relato le responde ubicándoles en algunos de sus distritos más turísticos a la par que emblemáticos: primeramente, deambulan por las calles colindantes al Sagrado Corazón descendiendo por las escaleras que conectan a las Rues du Chevalier de la Barre y Lamarck [49:35]. La distancia existente entre el anterior arrondissement y el actual (el 18 $\left.{ }^{\text {ème}}\right)$ es mostrada cinematográficamente bajo la licencia secuencial que, en su correspondencia real, supone un recorrido de alrededor de 50 minutos a pie. Aplicando la lógica espacial y temporal, se considera que el siguiente escenario por el que pasean podría extenderse entre la Place de Clichy y el Boulevard de Rochechouart ( 9 y $18^{\text {ème}) ; ~ y a ~ q u e, ~ a d e m a ́ s ~ d e ~ e n c o n t r a r s e ~ a ~ l o s ~ p i e s ~ d e ~ l a ~ c o l i n a ~ d e ~}$ Montmartre, durante décadas, y más especialmente durante los años 20, fue el área aglutinadora de las jóvenes dedicadas a la prostitución y que pueden apreciarse en el fondo de la panorámica que recoge el desplazamiento de la pareja protagonista de este fragmento narrativo [50:23-50:54]. La cámara regresa al punto urbano de partida del recorrido al ubicarse en las riberas del Sena que dan acceso al Puente Nuevo y que han sido comentadas en uno de los primeros apartados dada su presencia en el parcours. Únicamente añadir que el acceso a este puente se realiza a través del Quai des Orfèvres ( $\left.1^{\mathrm{er}}\right)$, uno de los que acota la citada Place. Esta tercera vivencia en el tiempo narrativo pasado finaliza en un bar [51:52] en el que, a diferencia del "habitado" por Hemingway, no presenta ningún distintivo que permita su reconocimiento, si bien, atendiendo al sistema del realizador, debe ser otro de los asociados a los artistas de la época al hacer que Gil coincida con algunos de los nombres más relevantes del surrealismo: Salvador Dalí (Adrien Brody), Luis Buñuel (Adrien De Van) y Man Ray (Tom Cordier).

La cuarta experiencia de Gil compartida con los personajes del pasado se inicia en el [59:13] cuando, nuevamente, el coche de época pasa a recogerle por la Église de Saint-Étienne al ritmo de las campanadas de medianoche. Esta es una de las menos relevantes espacialmente, ya que el protagonista es mostrado, directamente, a su llegada al interior de la casa de Stein [59:45], negándose su descenso del vehículo y posterior entrada al edificio, como sí se 
ha reconocido para su primera visita al hogar del personaje interpretado por Kathy Bates.

Fig. 6 - Restaurante Paul ubicado en la Place Dauphine. Foto M. Tovar, noviembre de 2013.

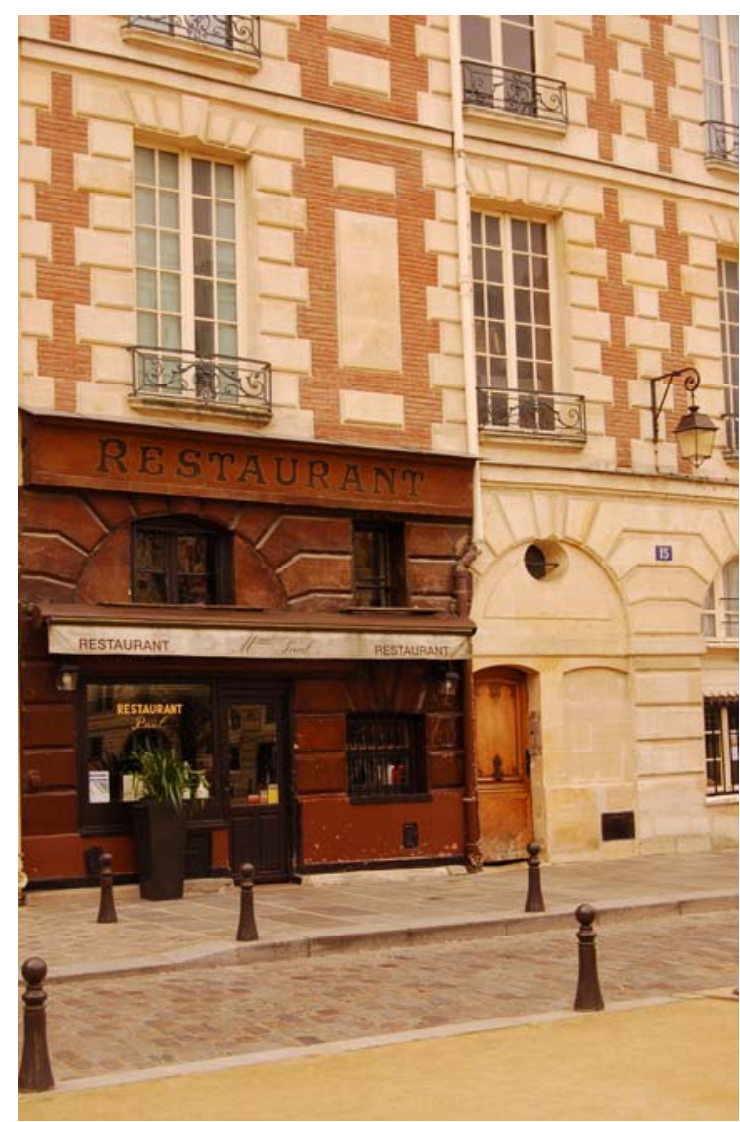

El quinto retroceso en el tiempo se inicia en el [01:10:06] cuando, a diferencia de los casos precedentes, la imagen muestra, directamente, al coche de época abandonando la zona en la que siempre recoge a Gil. Siguiendo el esquema de la porción anterior, la cámara vuelve a introducirse en la casa de Stein [01:10:12] para, después, hacerlo en la boutique de taxidermia y curiosidades naturales Deyrolle (7ème) [01:11:09], que es referida previamente en el diálogo facilitando su localización. Manteniendo los parámetros de su primera salida conjunta, Gil y Adriana regresan a la Place Dauphine que, en esta ocasión, es mostrada desde su otra perspectiva [01:13:16] y se sientan en la terraza de uno de los restaurantes que la habitan: Paul y cuyo nombre es brevemente apreciable en sus cristaleras. A pesar de que este es el último retroceso a ese pasado que dialoga con 
el presente del discurso durante su desarrollo, Allen amplía la complejidad de su narrativa al presentar un segundo nivel de lo precedente cuando en el [01:15:01] y a través del recurso que supone el paso de un momento histórico a otro (esta vez, un coche de caballos) traslada a la pareja a la Belle Époque. El largometraje responde a su naturaleza de muestrario acorde a cada uno de los fragmentos al retratar la entrada del representativo restaurante Maxim's ( $8^{\mathrm{èm}}$ ) [01:15:18] y en cuyo en interior penetra posteriormente. Destaca de entre las frases que intercambia la pareja protagonista, la referencia de Adriana a que había visto el lugar en fotografías, y lo hace por dos motivos correlativos: la joven niega su existencia al remitir a un pasado no coincidente con su presente ni, en consecuencia, con el de Gil; es decir, se interpreta de su afirmación que el negocio hostelero no existe para su realidad cuando, al igual que se ha remarcado para Polidor, no sólo sigue ubicándose en la misma dirección que originalmente, sino que, al mismo tiempo, ha mantenido intacta su distribución y apariencia exterior 9 . Siguiendo las matrices directivas aplicadas al resto de su largometraje, Allen concede a ese período también fundamental para la metrópoli parisina una nueva presentación a través de otro de sus iconos: el Moulin Rouge (18 ${ }^{\mathrm{eme}}$ ) [01:17:00] donde, como sucede a lo largo de la producción, hace coincidir a los personajes con autores relevantes del período: los artistas plásticos Henri de Toulouse-Lautrec (Vincent Menjou), Edgar Degas (François Rostain) y Paul Gauguin (Olivier Rabourdin). Sin embargo, el cineasta neoyorquino no cierra esta doble inmersión de Gil en el tiempo narrativo pasado anhelado por Adriana, sino que lo devuelve al suyo al trasladarlo a casa de Stein [01:22:08]; última conversación que le desvela la realidad emocional de su presente a la vez que le reta a superar su abnegación, tanto acorde a esa perspectiva como con respecto a la aceptación de su estado existencial verdadero.

Las premisas que se extraen del análisis de este fragmento apuntan a perspectivas ya tratadas matizándolas en diversos casos: en primer lugar, la repetición de los distritos retratados que, como ya se ha puntualizado, sólo se ven

\footnotetext{
${ }^{9}$ De hecho, el establecimiento realiza actualmente espectáculos que reviven algunas de las noches típicas de la Belle Époque y acoge en su interior un museo dedicado al Art Nouveau, tendencia artística que encontró en la capital francesa uno de sus lienzos urbanos más importantes a finales del siglo XIX y principios del XX, siendo una de sus mejores ejemplificaciones las múltiples estaciones de metro cuyos accesos están marcados por estructuras metálicas de diseño orgánico pintadas en verde y que sustentan paneles amarillos con el término Métropolitain.
} 
aumentados en uno gracias al fragmento rodado en el Museo de las Artes Feriantes situado en el $12^{\text {ème }} y$, a pesar de no haberse podido corroborar, posible y parcialmente también por el no 9 que, como se ha comentado, comparte protagonismo con el 18 en caso de que una de las escenas del paseo de Gil y Adriana tuviera lugar en los alrededores de Clichy/Pigalle/Rochechouart. En segundo, y relacionado con este, Allen se sirve de las elipsis narrativas para dotar de continuidad espacial a escenarios alejados en su existencia urbana. Reside en esta lógica del montaje otro aspecto relevante, y es que, en esa primera cita que tienen el protagonista y la musa de los artistas de los años 20, la cámara se traslada a la zona alta de la ciudad, uno de los puntos neurálgicos de la Belle Époque. Fue en los alrededores del Moulin Rouge, en las calles que bordean el Sacré-Cœur, en cabarets como "Le Chat Noir" y "Au Lapin Agile" (ambos en el 18 ${ }^{\text {ème}) ~ y ~ e n ~ m u c h a s ~ d e ~ l a s ~ b u h a r d i l l a s ~ d e ~ l o s ~ e d i f i c i o s ~ d e ~ s u s ~ c a-~}$ lles característicamente empinadas donde vivieron muchos de sus artistas, se impregnaron de las diferentes corrientes y movimientos, y participaron de la difusión de sus manifestaciones e ideas artísticas.

En este sentido, no se considera casual que Allen decida desarrollar en esa área parte de su narración, ni menos que sea la derivada del deseo de Gil de ser guiado por Adriana a través de la ciudad. Esta selección espacial se opone a la mostrada en el pasado anhelado por el protagonista: como se ha concretado para cada una de las ubicaciones, los momentos propios de los años 20 se corresponden, mayoritariamente, con los distritos números 5 y 6, este último habitáculo del barrio de Saint-Germain-des-Près, testigo de las reuniones y encuentros de los nombres más representativos del período. "Polidor", la casa de Stein, el bar en el que se presenta a los artistas españoles y a Ray (y que, presumiblemente, se localizaría en el barrio de Montparnasse); todos son emplazamientos que existieron e, incluso, se mantienen en la realidad testigos de lo que sucedió décadas atrás y que el director plasma a través de un ejercicio en el que la ficción y el género documental coexisten. En este sentido, se reconoce una práctica en cierta medida enciclopédica, aplicable a todo el largometraje y que es más notable para el caso del tiempo narrativo pasado: Allen sumerge al espectador en un momento artístico que, en el caso del perfil general, conoce a grandes rasgos y al que le concede la oportunidad de apreciar con mayor detalle haciéndole partícipe de conversaciones y situaciones que, en primera instancia, se entienden como verdaderas. Una muestra realis- 
ta, que, sin embargo y como se ha defendido, niega su contemporaneidad al no encontrar a su igual en el tiempo narrativo presente, ya sea a través de los diálogos como de la propia imagen.

\section{Conclusiones: medianoche en un París pluridentitario anhelado en el presente.}

De acuerdo a lo que se ha venido exponiendo a lo largo de los diferentes epígrafes, se concluye que Midnight in Paris, a pesar de recurrir al continuo diálogo de los tiempos narrativos propios de la década de 1920 y de 2011 se desarrolla en base al primero. Allen lo desvela desde uno de los fragmentos iniciales del discurso, aprovechando la visita de las parejas a los jardines de Versailles y transmitiéndolo a través de sus diálogos [10:57]

PAUL: ¿Y en qué época habrías preferido vivir tú, Don Quijote?

INEZ: París, años veinte. Bajo la lluvia.

GIL: No estaba tan mal.

(...)

PAUL: Es que la nostalgia es no querer ver un presente doloroso.

INEZ: Gil es un romántico rematado. Sería más que feliz viviendo en una ceguera perpétua.

PAUL: Y el nombre de esa falacia es 'Complejo de la Edad de Oro'. Sí, es la idea errónea de que cualquier tiempo pasado fue mejor que el que vivimos. Un fallo de la imaginación romántica de esa gente a la que le cuesta enfrentarse al presente $^{10}$.

Reside en este extracto tanto la presentación de la época soñada por Gil, como la propia moraleja aceptada por el personaje durante las últimas escenas de la película. Destaca de ello, también, el hecho de que el realizador mantiene una de sus características narrativas más estables y es la de convertir a los personajes en sus vías de comunicación: si bien se entiende que el escritor es su alter ego dadas las similitudes artísticas e, incluso, propias de la personalidad; Paul ejerce el papel del sentido común, de la lógica apuntando al final de la narración y que Allen establece aplicando las diferentes herra-

${ }^{10}$ El diálogo se corresponde con los subtítulos de la edición en DVD de la película consultada. 
mientas del medio cinematográfico. Asimismo, se aprecia en esta dualidad la asignación del pasado y el presente a esos dos personajes respectivamente y que remite a una doble identidad de la urbe que, a pesar de las diferencias temporales, es concéntrica en la mente del realizador, en el que cohabitan la nostalgia del pasado y la exploración y el disfrute del presente. En cierta medida, el cineasta declara su amor a la capital francesa sirviéndose del séptimo arte: París es mostrada inicialmente como un conglomerado de sus muestras arquitectónicas y turísticas; evidencia que no niega, a su vez, un resultado constitutivo e histórico. Con esto lo que se quiere decir es que, si bien el neoyorquino cae en la premisa establecida de grabar lo estereotípico, lo hace porque, por un lado, es lo que los propios medios y organismos nacionales reivindican como sistema enunciativo, referencial y atractivo para todos aquellos que muestran interés por visitar la ville lumière; se persigue, en suma, la estrategia implantada y que es la que, por sí misma, ha asignado a esos referentes la categoría de la redundancia y lo representativo. Pero, por el otro lado, todos esos elementos constituyentes del lienzo metropolitano son fundamentales para su identidad; no se puede negar su presencia, aunque sea mínimamente, porque ello conllevaría una omisión de su Historia.

París es el resultado de diferentes épocas y decisiones estructurales que son las que justifican que la Tour Eiffel sea su icono primero; que los ChampsÉlysées y el Arc que los determina sean un recurso reiterado dada la relevancia que siempre se les ha dado o que la Cathédral de Notre-Dame, entre otros muchos, aparezca en la práctica totalidad de producciones nacionales y extranjeras porque, además de todos los acontecimientos históricos de las que ha sido testigo, supone uno de los mejores ejemplos de arquitectura religiosa y coexistencia de estilos y movimientos artísticos del país. Cierta y notable es la estrategia publicitaria y promocional que se ha servido de todos estos referentes como lo es, igualmente, la aceptación por parte del director de que su mirada es la propia de un turista que, sirviéndose de las guías y materiales de similares rasgos, encontrará, normalmente, a estos como habitantes de sus páginas. En este sentido, se llega a una conclusión bicéfala con respecto a la selección de los decorados naturales mostrados en Midnight in Paris: Allen ofrece, como ya se ha especificado, una perspectiva reduccionista en términos espaciales o constitutivos de la ciudad al posicionar su cámara en un número concreto de arrondissements; de ello surge esa secuencia de imágenes turísti- 
cas, habitadas por lo representativo y en las que se identifica una tendencia a recrear la esencia de las postales (como, por ejemplo, cuando ubica al "Moulin Rouge" en el centro del plano y ocupando toda su dimensión). Sin embargo, junto a esa mirada propia del visitante, se presenta la del conocedor de la metrópoli: diferentes selecciones visuales introducen al espectador en áreas poco exploradas (salvo, como se ha señalado, para aquel que tiene un cierto manejo o habita en ella y que identifica los escenarios mostrados), aquello típicamente parisino en cuanto, al ubicarse en las zonas centrales de la capital gala, participa activamente de su cotidianidad y de su configuración; pero, asimismo, se califica de típico en contraposición a lo popularizado puesto que, sin enunciarse continuamente en las producciones televisivas y cinematográficas, mantiene intacta esa categoría de lo tradicional, de lo no manipulado, de lo que disfrutan los ciudadanos de a pie y que, como se ha matizado en las primeras páginas, es uno de los principios que orientan las normas y propuestas colaborativas de los organismos parisinos para con el séptimo arte. Muchos de estos emplazamientos participan de esa recuperación y, sobre todo, homenaje que el cineasta ejerce con sus regresos al pasado: con cada inmersión, Allen recupera a algunas de las figuras más relevantes de la década de los 20. Ejerciendo sumas y restas en términos referenciales y a través de la presentación de los individuos en el universo ficcional, hace coincidir a algunos de los artistas en un mismo fragmento, para, posteriormente, eliminarlos percibiendo en esa ausencia una excusa para la incorporación de un nuevo nombre.

Sucede lo mismo, pero aplicando los parámetros de la negación, para las localizaciones: el trabajo realizado por el norteamericano y su equipo manifiesta el interés por captar cinematográficamente a aquellos símbolos de uno de los períodos artísticos más importantes para la ciudad parisina. Posicionar a la cámara en el Musée des Arts Foraines, "Deyrolle", la Place Dauphine y "Maxim's" participa de ese principio de documentación ya referido, pero, sobre todo, de la realidad de una urbe que predica con el deseo de mantener intacto aquello que ha sido determinante para ella. El hecho de que todos estos escenarios mantengan, grosso modo, sus aspectos originales supone una reivindicación del elemento urbano para considerarlo como una secuencia histórica en la que lo anterior sólo puede comprenderse como resultante de su momento primigenio pudiendo cohabitar con lo propio de otras etapas. Esa defensa de lo único, de la identidad verdadera, explica que, a diferencia de las 
primeras películas con desarrollo en París y que reconstruían la mayoría de los decorados, la estudiada se haya podido servir de unos reales, cuidados y que siguen reviviendo años pasados.

No se expresa en los mismos términos el autor de la cinta al negarse, como se ha apuntado con anterioridad, su presencia actual. Esto se justifica si se tiene en cuenta el planteamiento final que se ofrece y que, como se expone líneas más abajo, obliga a una experiencia del presente en la que lo anterior es asumible siempre y cuando exista algo tangible que lo permita; es decir: Gil puede seguir escuchando la música de Cole Porter porque se venden discos de vinilos con sus grabaciones, pero no puede sentarse en ninguno de los asientos del "Polidor" dada su ausencia en la realidad ficcional. Así, Allen le expone al espectador la idea de que, a pesar de no mantener su estatus de constituyentes, todos ellos son fundamentales para la metrópolis actual como esencia mantenida, influencia intangible escasamente modificada con el paso del tiempo. Asimismo, esa atemporalidad también se desvela para un caso concreto del escenario urbano y que son los muelles del Sena, específicamente, el que se extiende bajo el Pont Neuf: por él pasean Gil y Adriana durante su primera cita y allí es a donde acude el primero cuando, soñando con esos años a los que accede a partir de medianoche, decide aprovechar esa experiencia para convertirla en su tiempo presente paralelo o secundario. Un ejemplo de que, efectivamente, el pasado se amolda a la contemporaneidad metropolitana sin perder su identidad y experiencia propias; modelo que coprotagoniza el cartel promocional del largometraje anticipando la dualidad narrativa enunciada, y valoración que el mismo director expresa a través de Gil cuando este expone que no hay forma artística que pueda oponerse a una gran ciudad, ya que, mirando alrededor, cada calle, cada bulevar, tienen una forma de arte propia [49:52].

Frente a todos estos apuntes, ese sueño y deseo del pasado manifiesto en el tiempo presente y, de acuerdo a lo defendido, naciente en la figura del realizador quien demuestra la ambivalencia residente en él mismo dificultando la valoración global de Midnight in Paris. Si se tienen en cuenta los postulados anteriores, siempre interpretándolos desde una perspectiva fílmica, Woody Allen niega la cohabitación de los diferentes períodos históricos en el universo narrativo o ficcional. Por contra, si se examinan los títulos de crédito finales se cerciora que, como se ha remarcado, las localizaciones son reales, lo que 
determina que, en efecto, todos esos espacios pasados existen en la actualidad y destaca que, precisamente, el realizador acabe recorriendo diferentes etapas sujeto a lo anhelado por varios de los personajes: mientras que el detective es trasladado al período versallesco (entre los siglos XVII y XVIII), Adriana se sumerge en la Belle Époque coincidiendo con artistas como Gauguin, quien matiza que ese presente es aburrido y que habría deseado vivir en el Renacimiento. Alusiones a momentos precedentes imposibles de experimentar, salvo por la magia fílmica, que remiten a la cita referida al inicio de estas conclusiones y que, primeramente despreciadas por Paul, acaban poniéndose en boca de Gil quien remarca el acto de escapar del presente en todos esos procesos de inmersión y adapta esas reminiscencias vividas a una realidad en la que la urbe se convierte en un lienzo cinematográfico particular aplicando las palabras de Alain Médam (2003: 9)

Somos habitantes y espectadores. Habitantes de nuestras ciudades. Espectadores de nuestras películas. (...) En nuestra vida diaria, en el transcurso de la vida, estos niveles de percepción se confunden y no sabemos muy bien si a falta de habitar nuestras películas no estamos escenificando, oníricamente, nuestras ciudades.

Una aceptación final también mostrada visualmente en la escena concluyente: el protagonista, por primera vez, no acude a las escaleras de la Église a medianoche como señalan las campanadas que suenan durante su paseo por el Pont Alexandre III. Su aparición en ese espacio coincidiendo con el recurso sonoro implica la unión de pasado y presente en la actualidad narrativa; lo acústicamente asociado a los años 20 se enuncia conjuntamente con lo turístico y emblemático que ha ocupado los primeros minutos del largometraje, anunciando la pérdida de la abnegación de Gil y, en consecuencia, su aceptación de un 2011 en el que, sin embargo, su década soñada seguirá latiendo. 


\section{Bibliografía.}

FEIGELSON, Kristian (2007): “La ville hybride. Paris réinventée (1930-2000)", en CRETON, Laurent y FEIGELSON, Kristian. Villes cinématographies. Cinélieux. Presses Sorbonne Nouvel. París.

GANNE, Valérie; Julliard-MOURGUES, Caroline y PRIOT, Franck (2009): Tourisme et tournage des films. Comment dynamiser son territoire par l'audiovisuel. ODIT (Observation, Développement et ingénierie touristique) France et Commission Nationale du Film-Film France. París.

LA RoccA, Fabio (2005): "L'esthétique de la ville au cinéma". Artículo del Grupo de Investigación GRIS (Groupe de Recherche sur l'Image en Sociologie) del Centre d'Études sur l'Actuel et le Quotidien de la Sorbona. Consultado el 19/02/2014. Recuperado de http://www.ceaq-sorbonne.org/node .php?id=1121\&elementid=798

LISARELLI, Diane (2011): "Paris a mauvaise Allen". Les Inrocks, edición digital. París. Consultado el 01/02/2014. Recuperado de https://www.lesinrocks.com /2011/04/08/cinema/paris-a-mauvaise-allen-1117189/

MEDAN, Alain (2003): “Introduction. Être de ville, être de film. Miroirs et réflexions", en PERRATON, Charles y JOST, François. Un nouvel art de voir la ville et de faire du cinéma. Du cinéma et de restes urbains. L'Harmattan. París.

MediaPRo, Versátil CinÉma y GRAVIER (Producción) y Allen, Woody (Dirección) (2011): Midnight in Paris. [DVD]. Madrid. Distribuida por Cameo.

MORA, Miguel (2012): “'Estoy de acuerdo: mis películas europeas son como guías turísticas'"'. Sección Cultura, edición digital ElPaís.com. Consultado el 14/02/2014. Recuperado de http://cultura.elpais.com/cultura/2012/09/04/ actualidad/1346784151_914775.html

REEVES, Tony (n.d.). "Midnight in Paris film locations". [Entrada de blog] Movie locations: the worldwide guide to movie locations. Consultado 19/02/2014. Recuperado de http://www.movie-locations.com/movies/m/Midnight_In_Paris.html

RETROTRAILERSPOT (Usuario registrado de YouTube) (11 de octubre de 2013). Everyone says I love you (1996) - Official Trailer [SD]. [Archivo de vídeo]. Consultado el 01/02/2014. Recuperado de http://youtu.be/p9NdzkqHSAw 
TOVAR, M. (2013). “La reversión de la triple personalidad de París en ‘Una cara con ángel' (Stanley Donen, 1957): el predominio de la visión turística de la ciudad". Arte y Ciudad. Revista de Investigación. № 3.1 extraordinario, junio 2013, pp. 135-152.

TRAILERS Y ESTRENOS (Usuario registrado de YouTube). (26 de abril de 2011). Midnight in Paris - Trailer en español. [Archivo de vídeo]. Consultado el 01/02/2014. Recuperado de http://youtu.be/VHx29JeGjMc

VV.AA. (2006). Charte des tournages à Paris. Entre la ville de Paris et les professionnels du Cinéma. Mairie de Paris y Mission Cinéma/Paris Film. París. Consultado el 06/12/2013. Recuperado de http://www.parisfilm.fr/ data/document/parisfilm-charte-tournagesfr.pdf

VV.AA. (2013). Rapport d'activité 2012 du Centre National du Cinéma et de l'Image Animée. Centre National du Cinéma. París. Consultado el 06/12/2013. Recuperado de http://www.cnc.fr/web/fr/publications/-/ressources/3812198

[N.A.] (n.d.). "Histoire du Bristol". Página web oficial del recinto hotelero Le Bristol. Consultado el 19/02/2014. Recuperado de http://www.lebristolparis. com/fr/a-propos-du-bristol/histoire-du-bristol/

[N.A.] (n.d.). “L'ensemble de l'Orangerie". Página dedicada a los diferentes cuadros constituyentes de la serie Les nymphéas de Claude Monet. Consultado el 19/02/2014. Recuperado de http://www.musee-orangerie.fr/homes /home_id24799_u112.htm

[N.A.] (2013). "Parcours cinéma". Mairie de Paris. París. Consultado el 06/12/2013. Recuperado de http://www.paris.fr/loisirs/balades-culturelles/ parcours-cinema/p8542.

[N.A.] (2011). Parcours cinéma dans Paris. № 13. 'Minuit à Paris'. Mairie de Paris y Mission Cinéma. París. Consultado 06/12/2013. Recuperado de http:// www.v2asp.paris.fr/commun/v2asp/v2/MIDNIGHTinPARIS_internet.pdf

[N.A.] (2011). "Progression de 9\% des tournages à Paris dans 2010". Communiqués de presse de la Mairie de Paris. París. Consultado el 06/12/2013. Recuperado de http://www.paris.fr/paris/Portal.lut?page_id=5777\&document_type id=7\&document_id=95000\&portlet_id=12645 